\title{
Radiographic control of mineral fibre-reinforced cement plates
}

\author{
Domanus, J.C.; Møller-Jensen, L.
}

Publication date:

1980

Document Version

Publisher's PDF, also known as Version of record

Link back to DTU Orbit

Citation (APA):

Domanus, J. C., \& Møller-Jensen, L. (1980). Radiographic control of mineral fibre-reinforced cement plates. Risø National Laboratory. Risø-M No. 2222

\section{General rights}

Copyright and moral rights for the publications made accessible in the public portal are retained by the authors and/or other copyright owners and it is a condition of accessing publications that users recognise and abide by the legal requirements associated with these rights.

- Users may download and print one copy of any publication from the public portal for the purpose of private study or research.

- You may not further distribute the material or use it for any profit-making activity or commercial gain

- You may freely distribute the URL identifying the publication in the public portal

If you believe that this document breaches copyright please contact us providing details, and we will remove access to the work immediately and investigate your claim 
RISO-M-2222

RADIOGRAPHIC CONTROL OF MINERAL FIBRE-REINFORCED

CEMENT PLATES

J.C. Domanus ${ }^{x}$ and L. Meller Jensen ${ }^{\circ}$

xuclear Department, Elsinore Shipbuilding Engineering Co., Ltd. DK 3000 Elsinore

'Special Fiber Department, Rockwool International Ltd., DK 2640 Hedehusene

Abstract. Paper accepted for pzesentation to the Third International Conference on Composite Materials in Paris, France, 26 29 August, 1980.

The usefulnes of the radiographic technique in the examination of Spinrock fibres reinforced cement plates was investigated with soft $\mathrm{X}$-rays.

A preliminary investigation has shown that soft $X$-rays are most suitable for radiography of cement plates, and therefore a $50 \mathrm{kV}$ $x$-ray machine with a $0.5 \mathrm{~mm}$ focus and beryllium window $x$-ray tube was used throughout the investigation. $x$-ray films of different speed and graininess were usec, and it was proved that a relatively fast Kodak Industrex $D$ film can produce radiographs of adequate quality. An Agfa-Gevaert Structurix IC paper can also be used.

March 1980

Risø National Laboratory, DK 4000 Roskilde, Denmark 
Radiographs of cement plates, taken both on X-ray film and paper were scanned using a transmission or reflection densitometer. optical density readings from the densitometer were fed into a paper chart recorder.

The results of the radiographic test were transferred to a quantitative measure by densitometer scanning from which the relative standard deviations in the optical densities were used. These measures show a significant correlation with the flexural strengths, measured on the same specimens.

We therefore conclude that the material distribution can be measured $c_{i} X$-ray radiography, and that this distribution is a very important parameter for the evaluation of the quality of cement plates reinforced with discontinuous mineral fitres.

INIS descriptors. CEMENTS, COMPOSITE MATERIALS, DENSITOMETERS, FIBERS, IMAGE SCANNERS, INDUSTRIAL RADIOGRAPHY, PAPER, PHOTOGRAPHIC FILMS, PLATES, SOFT X RADIATION, X-RAY RADIOGRAPKY.

UDC $620.179 .15: 537.531: 691.32$

Work performed under contract with Risø National Laboratory

ISBN 87-550-0661-2

ISSN 0418-6435

Risø Repro 1980 
CONTENTS

Page

INTRODUCTION

STATEMENT OF PROBLEM

SCOPE OF INVESTIGATION $\ldots \ldots \ldots \ldots \ldots \ldots \ldots \ldots \ldots \ldots \ldots \ldots \ldots \ldots$

Specimen Preparation ........................... 8

Preparation Procedure ......................... 8

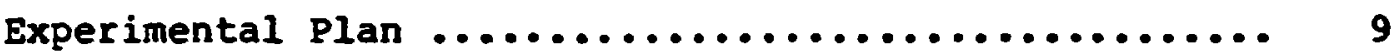

APPARATUS FOR THE RADIOGRAPHIC EXAMINATION $\ldots \ldots \ldots \ldots \ldots \ldots .9$

$x$-ray Machine ............................. 9

X-ray Film and Radiographic Paper ................ 9

Scanni.zg spparatus ......................... 10

PRINCIPLE OF THE RADIOGRAPHIC SCANNING $\ldots \ldots \ldots \ldots \ldots \ldots \ldots \ldots 11$

RADIOGRAPHIC EXPOSURE TECHNIQUE ................. 13

SCANNING PROCEDURE AND RESULTS $\ldots \ldots \ldots \ldots \ldots \ldots \ldots \ldots \ldots \ldots \ldots \ldots$

CALIBRATION POSSIBILITIES $\ldots \ldots \ldots \ldots \ldots \ldots \ldots \ldots \ldots \ldots \ldots \ldots \ldots$

EVALUATION OF DISTRIBUTION $\ldots \ldots \ldots \ldots \ldots \ldots \ldots \ldots \ldots \ldots \ldots \ldots$

MECHANICAL TESTS $\ldots \ldots \ldots \ldots \ldots \ldots \ldots \ldots \ldots \ldots \ldots \ldots \ldots \ldots \ldots \ldots$

RESULTS AND DISCUSSION $\ldots \ldots \ldots \ldots \ldots \ldots \ldots \ldots \ldots \ldots \ldots \ldots \ldots \ldots$

CONCLUSIONS FROM THE RADIOGRAPHIC INVESTIGATION ....... 18

GENERAL CONCLUSIONS ......................... 19

REFERENCES $\ldots \ldots \ldots \ldots \ldots \ldots \ldots \ldots \ldots \ldots \ldots \ldots \ldots \ldots \ldots \ldots \ldots \ldots \ldots \ldots . \ldots \ldots$ 


\section{LIST OF FIGURES}

Fig. 1. Scanning apparatus for X-ray film.

Fig. 2. Scanning apparatus for radiographic paper.

Fig. 3. Characteristic curves of $x$-ray film and paper at $30 \mathrm{kv}$.

Fig. 4. Radiograph of a $7 \mathrm{~mm}$ thick plate.

Fig. 5. Scans taken from X-ray film and radiographic paper.

Fig. 6. Graphical picture of the correlation between Flexural strength and distribution. The dotted line represents the least square linear fit.

Fig. 7. X-ray radiographs of the examined plates.

\section{LIST OF TABLES}

Table 1. Results from the radiographic and mechanical test at the 8 plates.

Table 2. Analysis of variance of table 1. 


\section{INTRODUCTION}

From the beginning of this century, asbestos cement products have increasingly been used within the building trade. which means that their consumption is estimated to form about $30 \mathrm{milli}$ in tons a year at present [1].

Because of the danger to health, which is connected with production and application of asbestos-containing materials [2], a large development work has taken place lately to try to develop types of fibres, which can replace asbestos. There are many demands on such fibre types and in excess of the primary requirements (for example, the mechanical properties, durability in cement and good adherence to cement) it is desirable that the present production methods can be used.

The two dominant production methods (the Hatschiek and the Magnani processes) [3] in principle consist of a preparation of an aqueous slurry of cement and fibres. The slurry is filtered off on a woven felt and this process results in a sheet which is moulded and cured. In the processes, only discontinuous fibres can be used, and the fibre distribution cannot be controlled directly, but is dependent on other fibre parametres, production processes and equipment.

\section{STATEMENT OF PROBLEM}

In the development of cexent products reinforced with other kinds of fibres than asbestos it is important to be able to separate the effect of the parametres which influence the results, as a satisfactory result is a compromise between materiai and process variables.

The purpose of this investigation was to try to find a method which is easy to use for measuring the uniformity of the fibre distribution.

Although it is possible to measure the uniformity of the fibre distribution by counting the quantity of fibres in a grating $y$ microscopy of surface grind, this method is very time-consuming and uncertain, especially with certain types of fibres. This is the case with the fibres used in this investigation, as they have a low mean diameter, and the fibres are difficult to distinguish from the cement matrix, because the colour. of the fibres is almost that of the cement matrix.

\section{SCOPE OF INVESTIGATION}

In this investigation we therefore chose to try to measure the fibre distribution by radiography and investigate the importance of differences in the fibre distribution by correlating the result from the radiographic measurement with the flexural strength of the sample specimen.

Introductory examination of a test plate has shown that cement ylates of this type can be best radiographed with soft $x$-rays (below $50 \mathrm{k} . \mathrm{V}$, with a beryllium window $x$-ray tube). X-ray radiographs can be taken both on $x$-ray $f i l m$ and on radiographic paper [4]. Densitometric scanning of radiographs can be performed on a scanning table either by a transmission (for $x$-ray films) or reflection (for radiographic paper) denitometer $[5,6]$.

To be able to detect inhomogeneities in the plates they are produced as plates with constant thickness. To avoid noxious effects of scattered radiation at the edges, the plates shall have even and smooth edges. 
According to these recomendations 8 test plates were produced.

Their dimensions are $115 \times 240 \mathrm{~mm}$ and they have thicknesses from 7.0 to $10.5 \mathrm{~mm}$.

All the above plates were radiographed on $X$-ray film and radiographic paper and the radiographs were thereafter scanned with densitometers. The results of the scanning were recorded on a serip chart recorder.

The investigation consisted of:

1. Choice of exposure factors ( $k V$, mimin, focus-film-distance) for each plate so as to obtain radiographs of the highest quality.

2. Choice of $\mathrm{X}$-ray film and radiographic paper.

3. Choice of scanning table and chart recorder speed for the scanning of radiographs.

4. Choice of chart recorder sensitivity.

5. Choice of aperture in the densitometer during scanning.

6. Taking of radiographs of the 8 plates on $x$-ray film and radiographic paper.

7. Scanning of radiographs.

8. Investigation of the correlation between the scanning results and mechanical properties of the plates.

\section{Specimen Preparation}

This investigation was carried out with cement plates made in the laboratory and reinforced with Spinrock alkali-resistant fibres as the only fibre component.

Cement: Normal Danish Portland Cement with a Blaine number of $320 \mathrm{~m}^{2} / \mathrm{kg} \mathrm{was}$ used without any additives.

Fibres: Spinrock alkali-resistant fibres, produced by Rockwool International, Denmark, is a mineral fibre, especially developed for application in cement. Two different types were used in this investigation: [7]

Average length

DPX

DX
Average diameter

$5 \mu \mathrm{m}$

$5 \mu \mathrm{N}$
Tensile strergth

$1500 \mathrm{MPa}$

$1500 \mathrm{MPa}$

\section{Preparation Procedure}

For each plate a total of $400 \mathrm{~g}$ of cement and fibres was used. The fibres were dispersed in the quantity of water, concordant with the siurry concentration used, and mixed for 5 minutes 1r. the laboratory pulper with a speed of 1000 rpm. The cement is added and the mixing procedure is repeated. The slurry is then filtered off in a laboratory sheet former with a wire mesh with 150 um openings, under a vacuum of $0.8 \mathrm{~m}$ water column. The dimension of the sheet is $25 \times 12 \mathrm{~cm}$. Finaliy 
the sheets are compressed with a pressure of $6 \mathrm{MPa}$, cured for one week at $20^{\circ} \mathrm{C}$ ano 100 $\mathrm{rh}$, and dried out for $24 \mathrm{~h}$ at $110^{\circ} \mathrm{C}$.

\section{Experimental Plan}

As previously mentioned, it is nct possible arbitrarily to control the fibre distribution with discontinuous fibres. The investigation was therefore planned as a $2^{3}$ factorial design with the following [8] three factors which in our experience will affect the fibre distribution.
A. Fibre length
B. Fibie content
C. Slurry concentration

Re A: Two types of fibres, DPX and DX, with average length of 150 and $800 \mu \mathrm{m}$, corresponding to aspect ratios of 30 and 160 were used.

Re B: We used two different fibre contents, 5w: and 15ws of dry material. These concentrations represent the assumed realistic upper and lower limits of the content of Spinrock fibres in cement.

Re C: The slurries were prepared with the following concentrations: 6.7 W8 and 25 ws of dry material in water. These two concentrations were selected, as they are representative for the concentrations used in the Hatschek and Magnani process.

\section{APPARATUS FOR THE RADTOGRAPHIC EXAMINATION}

$\underline{x-r a y}$ Machine

The preliminary investigation [9] has shown that soft $X$-rays should be used for radiography. Such radiation can be obtained from a beryllium window $x$-ray tube operating in the low $\mathrm{kV}$ range. The Balteau 5-50 kV X-ray machine was used, with a $0.5 \mathrm{~mm}$ focus, beryllium window $\mathrm{x}$-ray tube. This machine can be used from 5 to $50 \mathrm{kV}$ at a maximum of 10 (at $50 \mathrm{kV}$ ) to 20 (at $25 \mathrm{kV}$ ) $\mathrm{mA}$. The $\mathrm{x}$-ray tube, with grourded anode, is water coolea.

\section{X-ray Film and Radiographic Paper}

Kodak Industrex $M, C$ and $D X$-ray films, having different speed and graininess, were tested. It was proved that the relatively fast $D$ film can produce radiographs of adequate quality (sharpness, contrast) and at the same time can reduce exposure time. The $x$-ray film is used without intensifying screens.

Radiography on paper was made with the Agfa Gevaert Structurix IC paper. A fluorescent intensifying screen, Structurix IC type II, was used.

$X$-ray films were processed by hand using the standard processing so?.utions (4 min development at $20^{\circ} \mathrm{C}$ ) whereas automatic processing (Structurix IC 50 ) was used for the radiographic paper (ca. 15 s processing).

Rigid aluminium cassettes were used both for the $x$-ray film and radiographic paper. Protection from scattered radiation around plate edges was assured by lead strips surrounding the plate.

Lead markers were used for identifying of radiographs. 


\section{Scanning Apparatus}

The scanning apparatus, shown on Figs. 1 and 2 , consists of a scanning table (1), on which X-ray film (3, Fig. 1) or radiographic paper (2, Fig. 2) is placed.

An electric motor (3) coupled to a gear-box (4) pulls the scanning table by means of the rod (5), under the densitometer (6). By means of the gear-box 10 different scanning speeds can be chosen.

Film (or paper) density measured by the densitameter (5) is recorded on the strip chart recorder (7). The movement of the scanning table is controlled by the pane 1 ( 8 ).

The measuring probe of the reflection densitometer is shown as (9) on Fig. 2 .

X-ray film density is measured during scanning by a transmisision densitometer. The Macbeth Quanta Log TD 100 densitometer (Fig. 1) is used. Radiographic paper density is measured by a reflection densitometer (Fig. 2). There, model R70B of the Electronic Systems Engineering Co. densitometer is used.

Density measurements are recorded on $(7)$. This recorder has several paper speeds and recording sensitivities. A Hewlett Packard 7100 Strip Chart Recorjer was used.

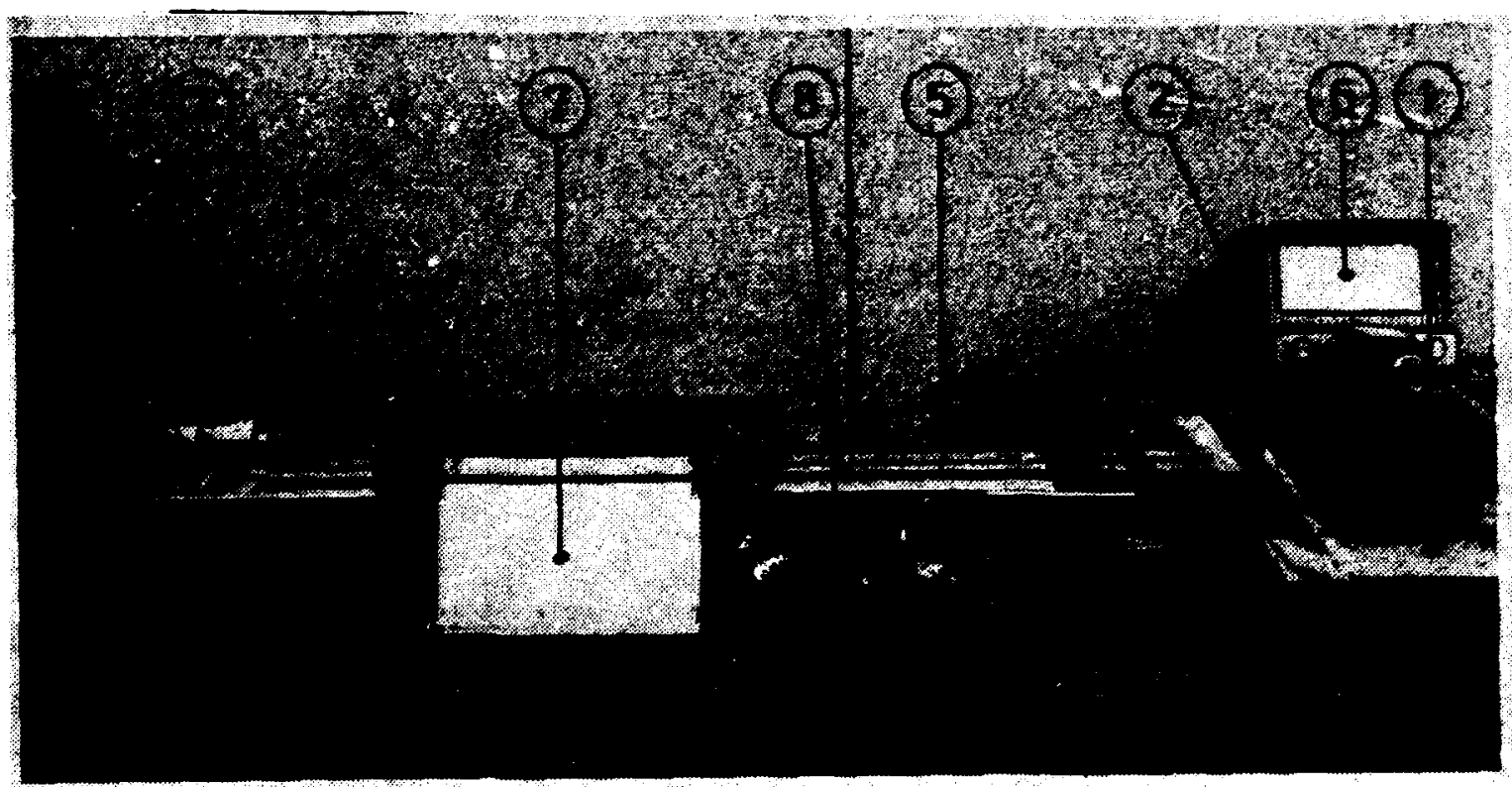

Fig. 1 Scanning apparatus for X-ray film 


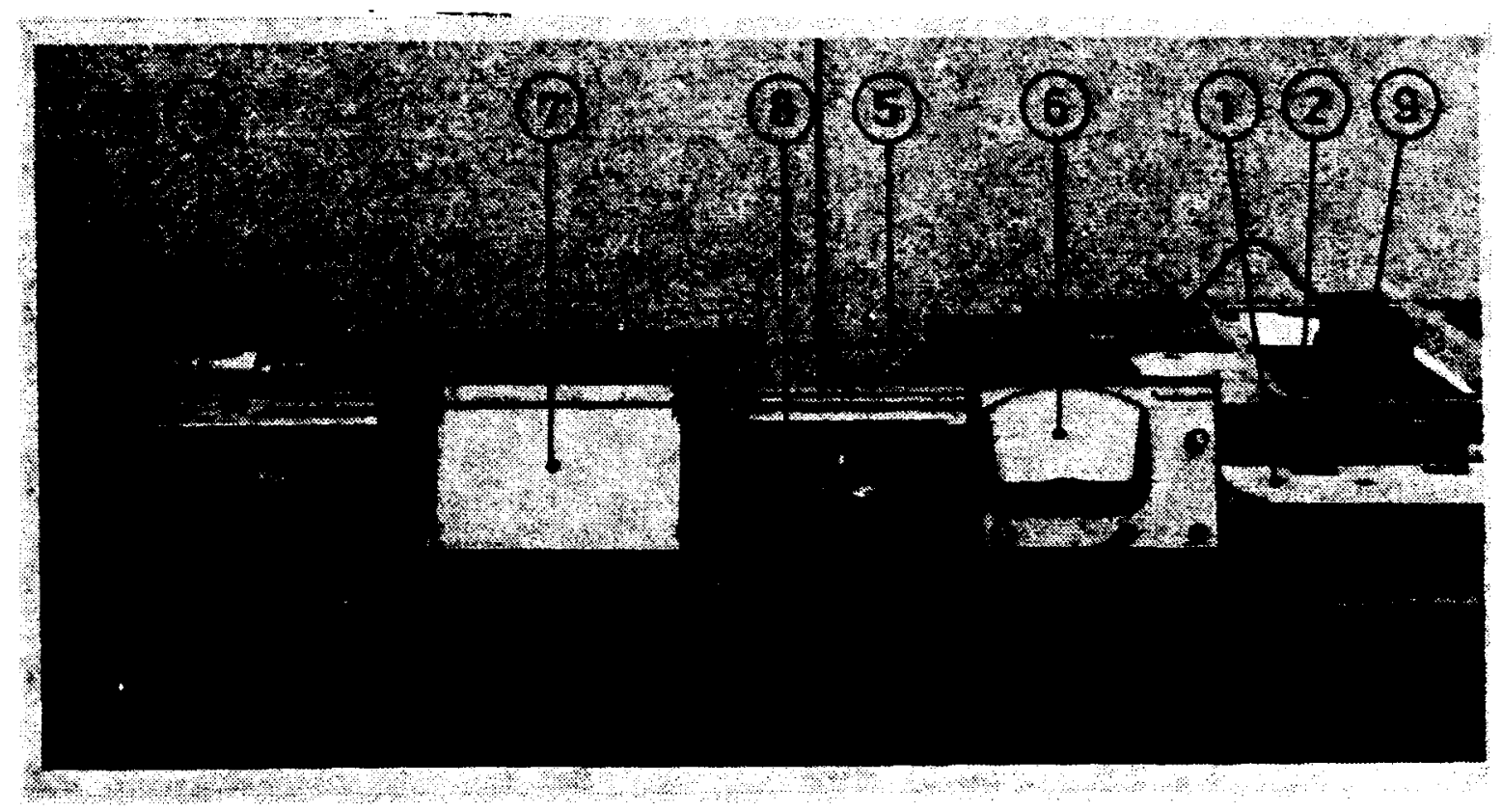

Fig. 2 Scanning apparatus for radiographic paper

\section{PRINCIPLE OF TIEE RADIOGRAPLIIC SCANNING}

The attenuation of $x$-rays emitted from an $x$-ray tube occurs according to the following law:

$$
J=J_{0} e^{-\mu x}
$$

where: $J$ - intensity of $x$-rays impinging upon the plate under examination;

$J^{\circ}$ - intensity of $x$-rays which have passed the plate and enter the $x$-ray film or paper;

H - linear attenuation coefficient;

$x$ - plate thickness.

During the radiographic examination of a particular plate the plate thickness is constant and $x=d$, so that

$$
J=J_{0} e^{-\mu d}
$$

The attenuation coefficient $\mu$ depends both on the radiarion energy (kV) and the material properties of the plate. for a given expusure the radiation energy is constant, so the attenuation coefficient depenos only on the material properties of the plate under examination.

The optical density (D) of a radiograph is defined as:

$$
D=\log _{1} \frac{L}{L}
$$


where Lo $_{0} 15$ the ilght intensity ilpinging on the rediograph during viewing and I is the light intensity that has passed through the film or was reflected fron the perer.

If the plate is composed of anly one antertal (e.g. ceenent then $u$ will depend only on the physical dessity of this meterial; for higher density the $y$ will be higher and vice versa. The differences of density of a plate of constent thictess will be reveeled as differences of optical densities on the radiographs: higher opeical density means lower meterial density and vice verse.

If. however, the plate is composed of two (or ware) different anterials with dissimilar attenuation properties (e.g. Canent and glass fibre), the resulting attenuation coefficient will depend on the relative composition of those waterials. For a plate of constant thichness the differences of composition of those naterials will be revealed as differences of optical density on the radiographs.

As can be seen, the inhorogeneities of the plate composition manifest thenselves as differences of the attenuation coefficient $u$ and will result in differences of $X-r a y$ intensities $J$ reaching the Eilm or paper. This intensity J mitiplied by the exposure time $t$ gives the film or paper exposure.

$$
\mathbf{E}=\mathbf{J} \cdot \mathrm{t}
$$

The optical density of the $x$-ray $f_{i l m}\left(D_{f}\right)$ or paper $\left(D_{p}\right)$ depends on this exposure $E$. The relation between the optical density and the expcsure:

$$
D=\boldsymbol{E}(\boldsymbol{E} \text {. }
$$

is called the characteristic curve of X-ray film or paper.

Figure 3 shows characteristic curves of the Kodak Industrex $D X$-ray film lexposed without intensifying screen) and Agfa Gevaert structurix IC paper (exposed with IC II screen) taken at $30 \mathrm{kV}$. The curves are produced as:

$$
D=E(\log E)
$$

As can be seen the optical density of an X-ray film increases constanty with exposure, whereas paper densicy reaches a saturation level.

From the characteristic curves paper or film contrast ( $y$ ) can be calculated as:

$$
\gamma=\operatorname{tg} \alpha
$$

The filw contrast (in the practicable range) is usually higher than the highest paper contrast, which means that amall vartations in plate homogeneity will be more noticeable on the film chan on paper, because for tie same difference of exposure $J E$ larger difference of optical density can be groduced on iilm ( $D_{f}$ ) than on paper $\left(L D_{E}\right): L D_{E}>L D_{p}$

ilaving produced radiographs of the plates under examination, those radiographs are thereafter submitted to a scanning procedure, during which the radiograph is pulled under a densitoneter, which measures the petical density and records it on $a$ strip share recorder. 


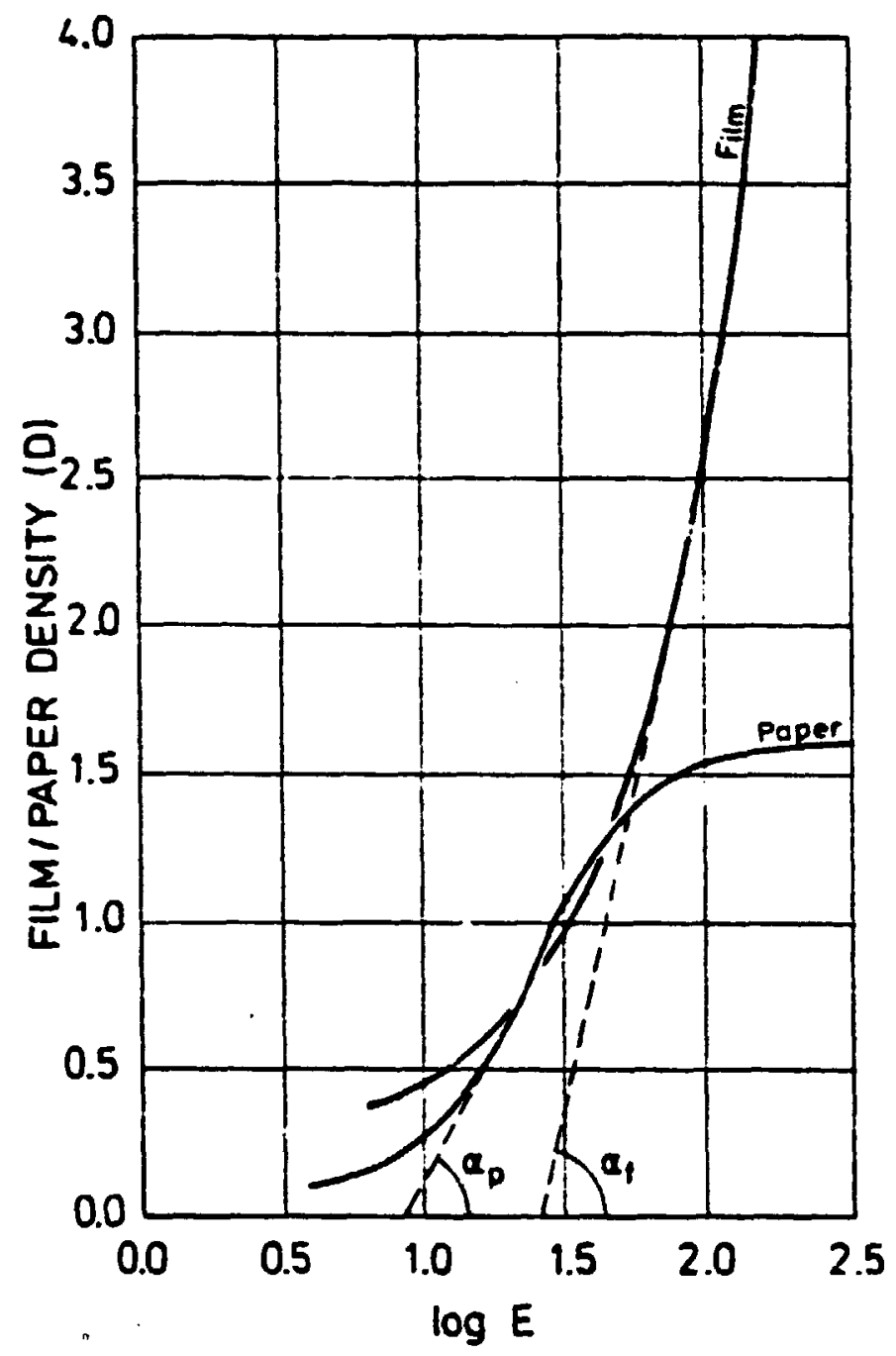

Fig. 3 Characteristic curves of $\mathrm{X}$-ray $\pm \mathrm{ilm}$ and paper at $30 \mathrm{kV}$

\section{RADIOGRAPHIC EXPOSURE TECHNIQUE}

First, all the 8 plates were radiographed together on a $50 \times 60 \mathrm{~cm}$ paper at $32.5 \mathrm{kV}$ and a $120 \mathrm{~cm} F F D$. Thereafter two radiographs of each plate were taken on. radiographic paper: one for scanning purposes, the other for assessment at Rockwool. Th. se were taken at kilovoltages (kV) that will produce approximately the same paper density $\left(D_{p} \approx 1.0\right)$ at a constant exposure (mAmin) and FFD (cm).

For radiography on $x$-ray film the same kilovoltage was used as for paper. The exposure (mAmin) of all paper radiographs was the same.

A11 radiographs were taken at $15 \mathrm{~mA}$. The exposure time for $x$-ray film (producing densities of $D_{f} \approx 2.0$ ) was 10 min (films exposed without intensifying screens), whereas for radiographic paper (used with fluorescent intensifying screen) the exposure time was $3.5 \mathrm{~min}$.

Thus the Agfa'Gevaert structuric IC paper (with Structurix IC II screen) was about 3 times faster than Kodak Industrex $D$ film. 
The geometric unsharpness $U_{g}$ of the radiographs taken witt a 0.5 ma $x$-ray tube at a $F=500 \mathrm{~mm} F F$ of the plates of maximum thickness $d=10.5 \mathrm{~mm}$ can be calculated as follows:

$$
u_{g}=\frac{0 \cdot d}{F-d}=\frac{0.5 \times 10.5}{500-10.5}=0.01 \mathrm{~mm}
$$

This unsharpness is less than the internal unsharpness of either $x$-ray film or radiographic paper and can give sharp radiographs.

Figure 4 shows a photograph of an X-ray film radiograph of plate No. 2.

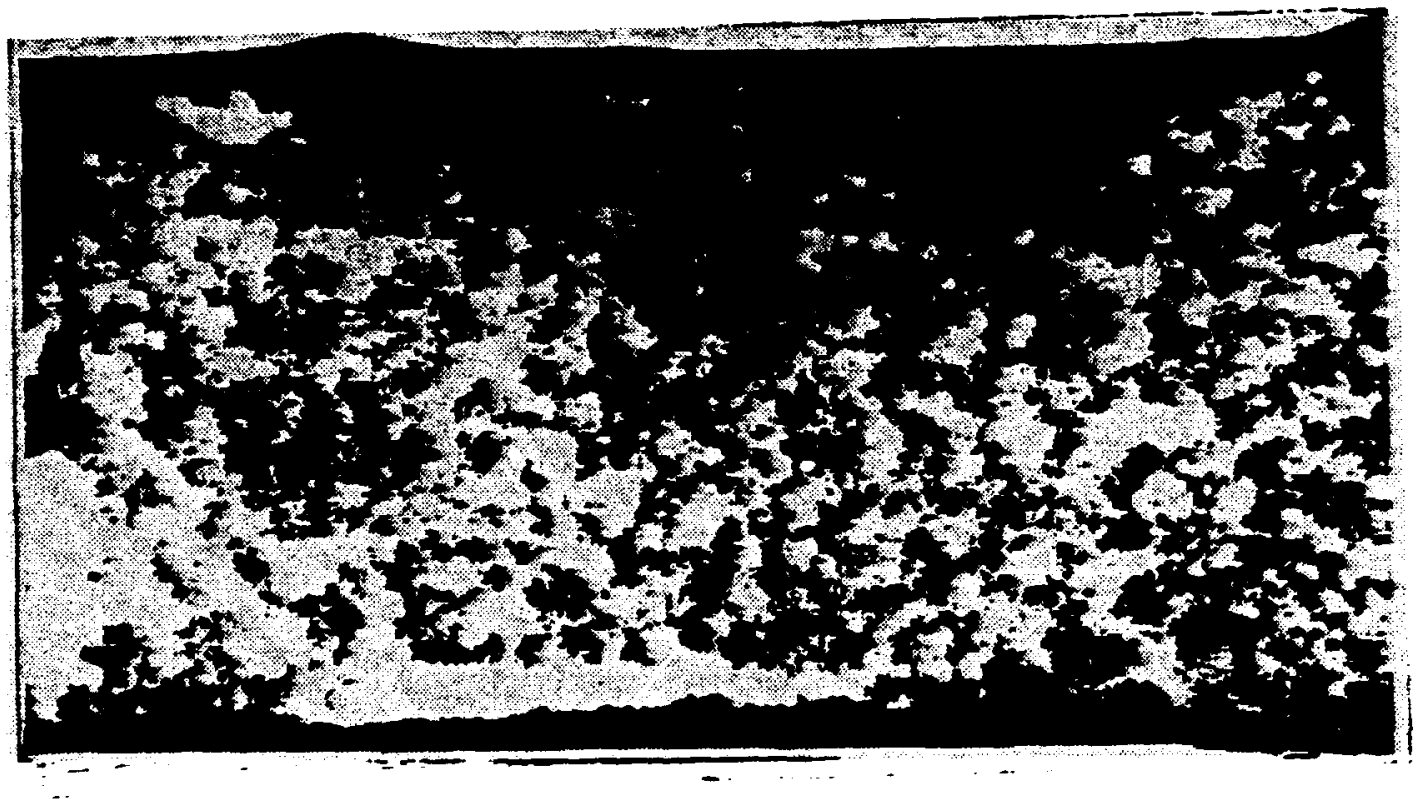

Fig. 4 Radiograph of a 7 mo thick plate

\section{SCANNING PROCEDURE AND RESULTS}

$\mathrm{X}$-ray film radiographs were scanned by the use of the transmission densitometer (6 on Fig. 1). This densitometer has three diaphragms of the following diameter: $1.0,1.6$ and $3.0 \mathrm{~mm}$, which give the scanning ared of $0.8,2.0$ and $7.0 \mathrm{~m}^{2}$. The reflection densitometer $(6$ on Fig. 2) has only ont diaphragm: 1.6 mo in diameter (scanning area $2,0 \mathrm{~mm}^{2}$ ).

To be able to compare the scanning results obtained from film and paper radiographs (of the same plate), on both densitometers the $\emptyset 1.6 \mathrm{~mm}$ diaphragm was used. Film radiographs of the same plate were also scanned using diaphragms of different diameter as well as different recorder sensitivities.

Figure 5 shows a photograph of two scans of the same RW2 plate: one (the upper) taken from a film radiograph and the other (the lower) from a paper radiograph. 

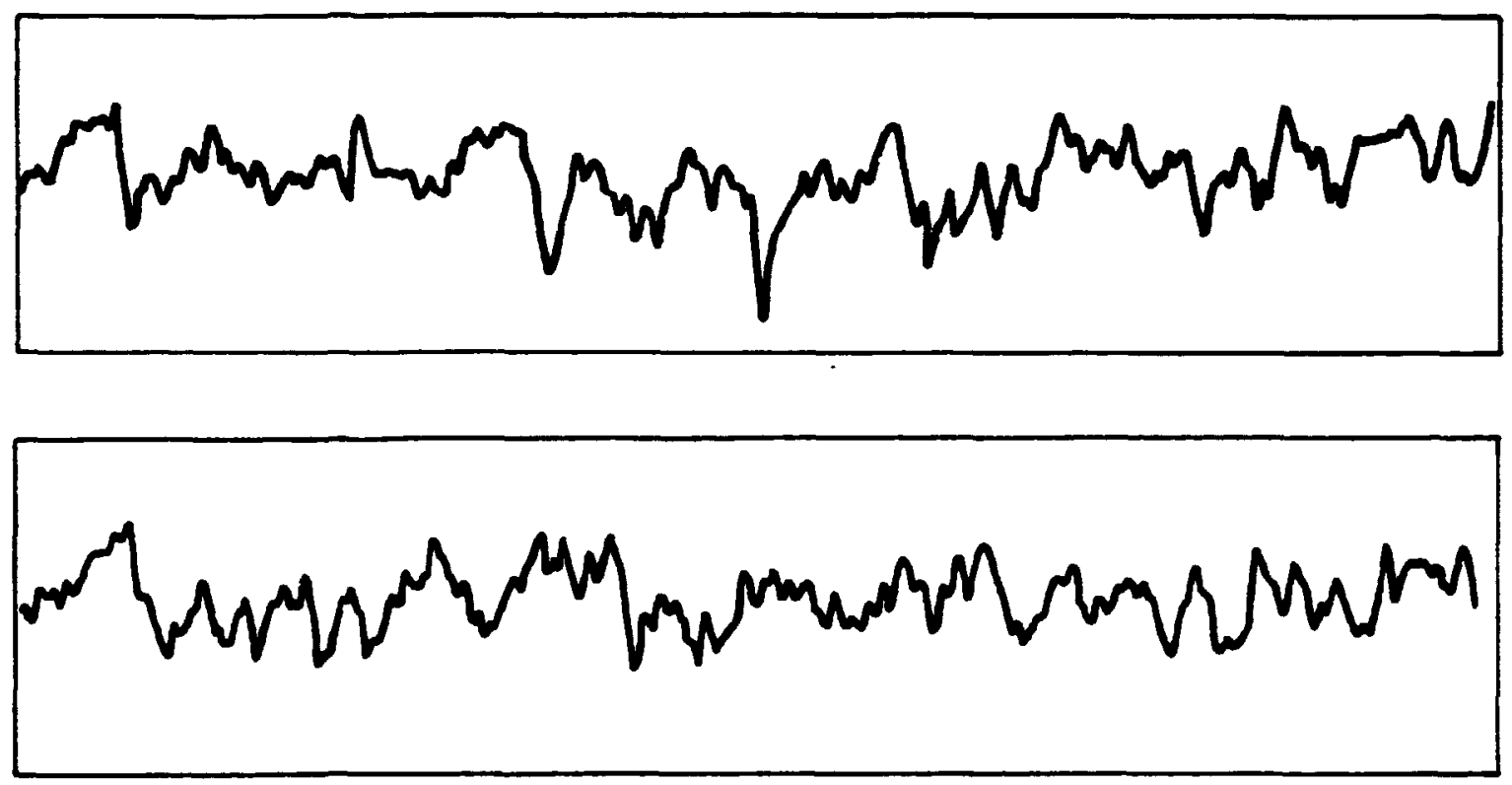

Fig. 5 Scans taken from $X$-ray film and radiographic faper

By comparing the scans of the same plate from $x$-ray film and radicgraphic paper taken under the same scanning conditions, one can see that radiographic scans from film show greater differences of optical densities than those from radiographic paper. This is due to the higher contrast of $x$-ray film than paper.

Comparison was made of the influence of the diaphragm diameter on the scanning results. The film radicgrams of a plate were scanned with $1.0,1.6$ and $3.0 \mathrm{~mm}$ diaphragms. As could be seen with the increasing diameter of the diaphragm maximum differences in optical density were slightly decreasing. In all those instances where one is not interested in homogeneity variations in the plate along a rather narrow strip but would like instead to have some more average results, one can use larger diaphragm apertures during the scanning.

To investigate the reproducibility of the scanning result for the same plate radiograph and scanning settings, for each aperture the scans have been repeated twice.

\section{CALIBRATION POSSIBILITIES}

To be able to assess quantitatively the findings of the radiographic scanning a calibration procedure can be developed along the following lines.

Samples of plates with known, calibrated content and coinposition of the materials from which the plates to be controlled are produced, can be made in thicknesses corresponding to the thicknesses of the plates under contrcl. Those calibration plates could be produced in such a way as to represent tolerance limits for the product under control. The calibration plates will be thereafter radiographed together with the other plates. After performing radiographic scanning for both the calibration plates and the plates under control one will be able to assess the radiograms and determine whether the tolerance levels, have not been exceeded. 


\section{EVALUATION OF DISTRIBUTION}

From the recorder strip, the optical densities were read with a distance of $2.5 \mathrm{~m}$ along the line where the densitometer scanning was made. On the basis of these masurements, the relative deviation (i.e. deviation in proportion to the level) was calculated as standard deviation in a logarithmic normal distribution. This deviation is as a quantitative expression of the distribution, used in the following, i.e. the larger deviation the poorer distribution.

The results of the calculation of the deviations of the 8 plates are shown in Table 1, whereas Fig. 7 shows the radiographs of all the plates.

\begin{tabular}{|c|c|c|c|c|c|}
\hline Plate no. & $\begin{array}{l}\text { TYpe of } \\
\text { fibre }\end{array}$ & $\begin{array}{c}\text { Fibre } \\
\text { cont. }\end{array}$ & $\begin{array}{l}\text { Slurxy } \\
\text { Conc. }\end{array}$ & $\begin{array}{c}\text { Distr. } \\
\text { deviation }\end{array}$ & $\begin{array}{c}\text { Flexural str. } \\
\text { MPa }\end{array}$ \\
\hline 1 & DPX & 5 & 6.7 & 1.1 & 18.5 \\
\hline 2 & DX & 5 & 6.7 & 9.3 & 11.7 \\
\hline 3 & DPX & 15 & 6.7 & 2.9 & 17.6 \\
\hline 4 & DX & 15 & 6.7 & 9.6 & 6.8 \\
\hline 5 & DPX & 5 & 25 & 1.9 & 15.1 \\
\hline 6 & DX & 5 & 25 & 4.0 & 13.5 \\
\hline 7 & DPX & 15 & 25 & 3.6 & 21.4 \\
\hline 8 & DX & 15 & 25 & 12.6 & 8.8 \\
\hline
\end{tabular}

Table 1 Results from the radiographic and mechanical test at the 8 plates.

\section{MECHANICAL TESTS}

The test plates were then cut out in specimens to test the flexural strength. Each plate was divided into 6 specimens with dimensions $3.5 \times 12 \mathrm{~cm}$ so that the middle of each specimen, where the rupture was assumed to take place during the test, was on the line where the densitometer scanning previously had taken place.

Thereafter the specimen was flexural strength tested under three point load with a span of $96 \mathrm{~mm}$.

The averages of the six measurements of each plate are stated in Table 1.

\section{RESUITS AND DISCUSSION}

To investigate if the calculated differences in the distribution (deviation) were in accordance with the messured differences in the flexural, strength, we cal- 
culated the correlation coefficient between the deviation and the flexural strength:

$$
\mathbf{r}=-0.82
$$

as it exceeds the 95t quantile in statistics tables, the correlation is statistically significant [10] and 67 of the variation in the results is covariational in deviation and flexural strength.

This correlation is graphically depicted in Fig. 6

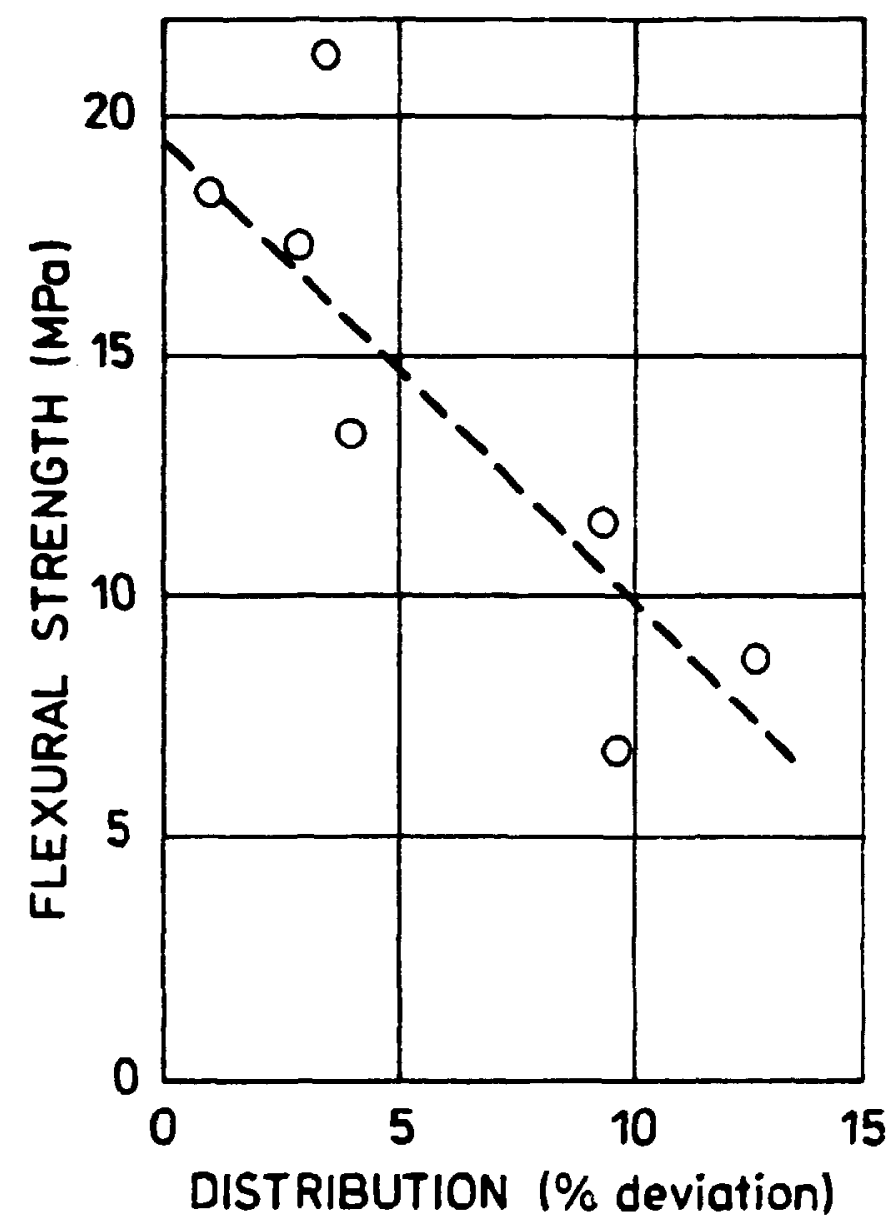

Fig. 6 Graphical picture of the correlation between flexural strength ani distribution. The dotted line represents the least square linear fit

To 1 llustrate the correlation further, we have carried out an analysis of rariance both for the distribution and the flexural strength as shown in Table 2 . This table shows that in both cases the fibre length has a very significant effect. This $i s$ in accordance with what we expected, that longer fibres are more difficult to distribute and therefore can result in inferior strength results. 
As to the cintent of Eibres, the analysis of variance (factor B) shows that increase in fibre content resules in a slightly inferlor distribution. whereas no effect is seen in the strength results. Normally an increase in Eibre content should result in an increase in wechanical strength. On the other hand higher fibre content is moze difficult to distribute. In this case we assume that these two opposite effacts are in balance so that no change is seen in the test results.

\begin{tabular}{|c|c|c|c|c|}
\hline $\begin{array}{l}\text { Source of } \\
\text { variation }\end{array}$ & $s^{2} d i$ & $\mathbf{F}$ & $s^{2}$ flex & $\boldsymbol{F}$ \\
\hline $\mathbf{A}$ & 85.5 & $18.8 * *$ & 126.4 & $30.8^{* *}$ \\
\hline B & 19.2 & $4.3(*)$ & $2.2-$ & 0.5 \\
\hline$A, B$ & 3.6 & & 28.1 & $6.9(*)$ \\
\hline c & 0.1 & & 2.2 & \\
\hline$A, C$ & 1.8 & & 1.4 & \\
\hline$B, C$ & 4.8 & & 6.8 & \\
\hline$A, B, C$ & a. 8 & & 6.1 & \\
\hline
\end{tabular}

Factor A - Fibre length

Factor B - Fibre content

Factor C - slurry concentration

* Significant at the 52 level [11]

**at the 13 level.

Table 2 Analysis of variance of table 1

\section{CONCLUSIONS FROM THE RADIOGRAPHIC INVESTIGATION}

From the above-described investigation the following conclusions can be drawn:

1. Densitometric scanning is a sensible method for the control of glassfibre-reinforced cement plates. It can detect inhomogeneities in plates with great accuracy.

2. For the control of plates described in this report soft $x$-rays shall be used, generated at kilovoltages below $50 \mathrm{kV}$ in a beryllium window $X$-ray tube.

3. Radiographs of the plates can be made either on a relatively fast $x$-ray fili or on radiographic paper. The latter is much cheaper than the former.

4. The quality of the paper radiographs is satisfactory. Although the conLrast of the paper is lower than that of the film, inhomogeneities in the plates can very well be revealed on paper radiographs. 
5. Exposure time for the radiographic paper is sirorter than for the $x$-ray $\hat{\mathbf{I}} \mathrm{l} l \mathrm{~m}$.

6. Processing of the radiographic paper is much faster than that of the film (can be done in about $15 \mathrm{~s}$ ).

7. An automatic processing machine for the radiographic paper is comparatively cheap, compact and does not require a water supply.

8. In view of the above facts paper radiographs can be recommended if routine control of the plates is envisaged.

9. Scanning of radiographs can be performed with a relatively simple apparatus. For the purpose ordinary transmission (for film) or reflection (for paper) densitometers can be used.

10. For routine scanning control of numerous plates it is worthwhile to design a special, simplified scanning table.

11. To be able to assess the results of the densitometric scanning quantitatively it is necessary to produce calibration plates with the desired homogeneity.

\section{GENERAL CONCLUSIONS}

The distribution, measured as the relative standard deviation from the densitometer scans is a very important material parameter as most of the variance in the strength results appears as covariance between the distribution and flexural strength in this investigation.

We find that the distribution is strongly influenced by the fibre length - the shortest fibres give by far the best distribution.

The distribution is also influenced by the fibre content, but to a small degree. Here we find that the lowest fibre content gives the best distribution.

we do not think that the slurry concentration in the preparation has any effect on the distribution.

\section{REFERENCES}

1 LIESEGANG, D. and BATZ, R., Umwelt, vol.4, 1978, pp.299-301.

2 NEWHOUSE, M.L., Envi ronment and Man, Vol.6, Pp.137-5;8.

3 KLOS, H., Asbestzement Technologie und Projektierung, Springer Verlag 1967.

4 DOMANUS, J.C. and MIKKELSEN, C., Comparison of $x$-ray film and paper radiography, Risø-M-1995, April 1978.

5 DOMANUS, J.C., Application of radiographic paper to quality control of MTR fuel elements. Nuclear Fuel quality Assurance. Froceedings of a Seminar on Nuclear Fuel Quality Assurance held by the International Atomic Energy Agency in Os10, 24-27 May 1976, IAEA, Vienna, 1976, Pp.349-359.

6 DOMANuS, J.C., Radiographic control of materials testing reactor fuel on X-ray paper, Nuclear 'T'echnoloyy, 36, 1977 Ito2, 187-192. 
7 Spinrock Fibres fram the Rockwool Group, issued by Rockwool International. Denmurk.

8 DAVIES, O.L., Design and Analysis of Industrial Experimentz, Oliver and Boyd for ICI, 1963.

9 Downus, J.C. and IHLFLF, B., Non-destructive control of fibre reinforced composites by soft $X$-ray radiography. Proceedings of the 1978 International Conference on Composite Materials, 16-20 April 1978, Toronto, Canada, 10721092.

10 MERRINGTON, M. and THOAPSOA, C.M., Biometrika, 101.33, Pp. 78-87, 1943.

11 MaLiBra, A.C., Statistiske Tabeller, G.E.C. Gad, $1 \leq 70$. 
Plate no. 1

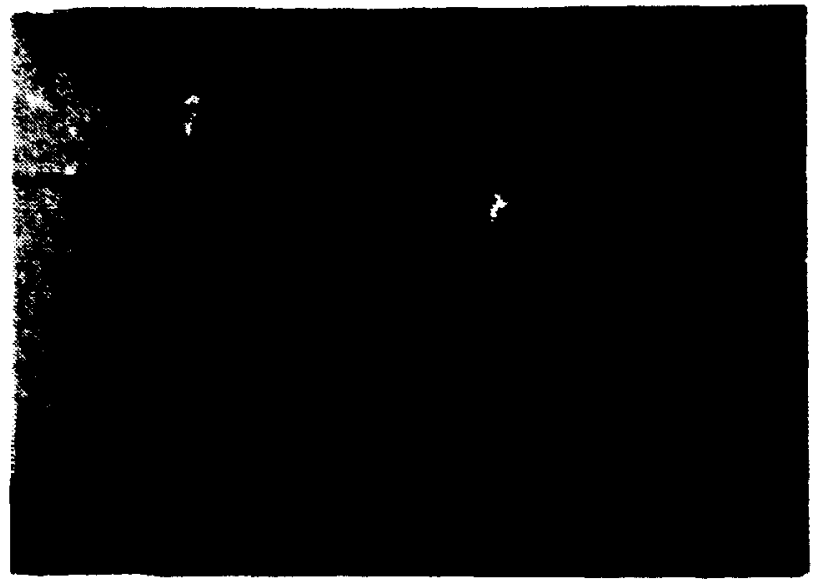

Plate no. 3

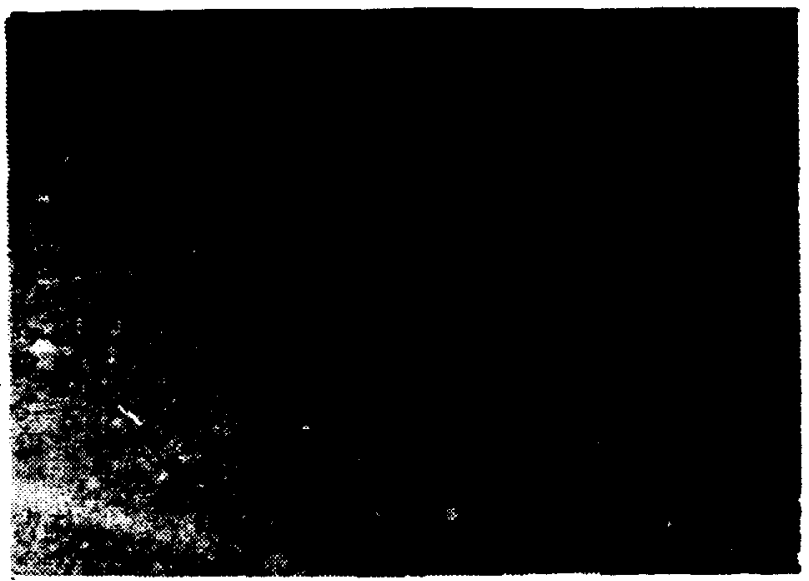

Plate no. 5

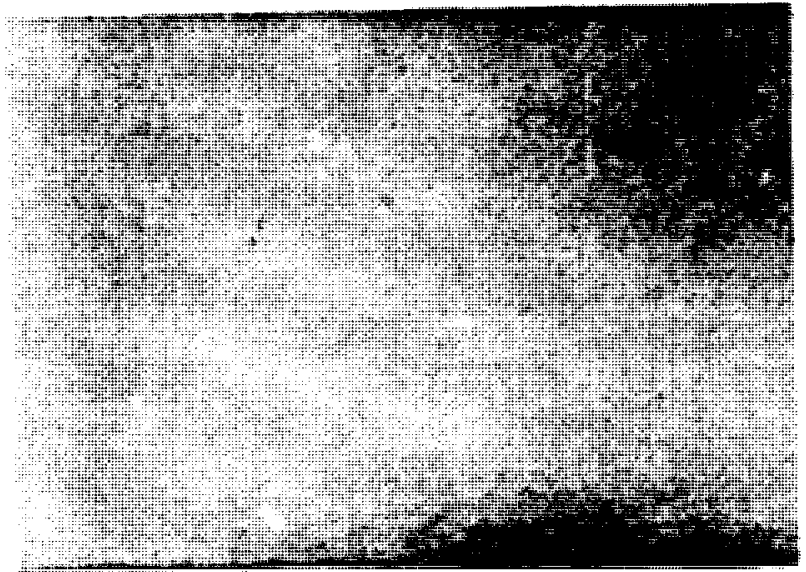

Plate no. 7

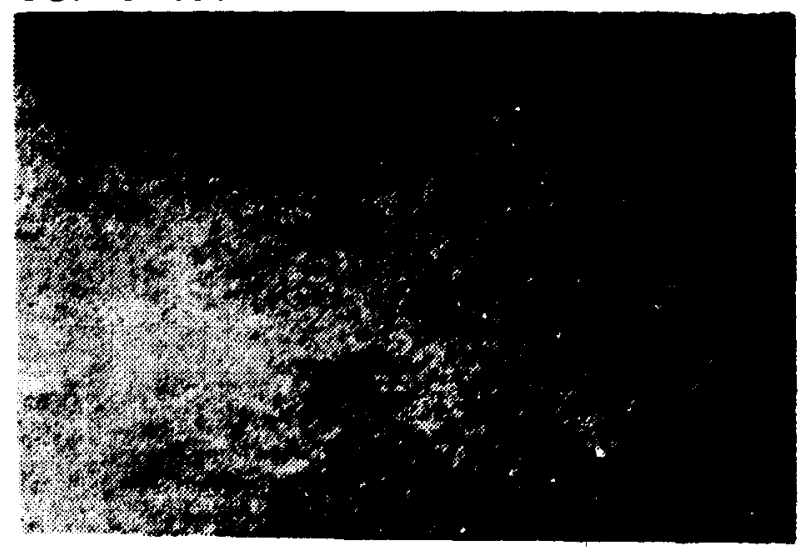

Plate no. 2

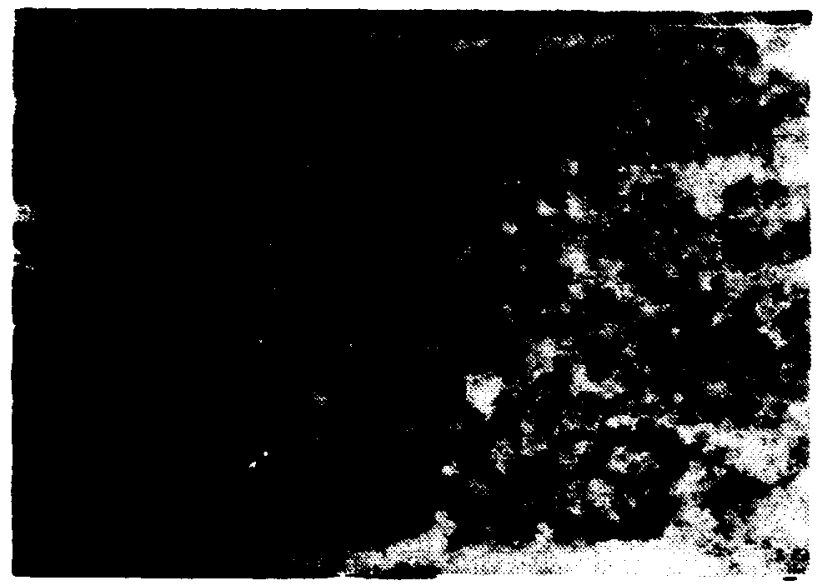

Plate no. 4

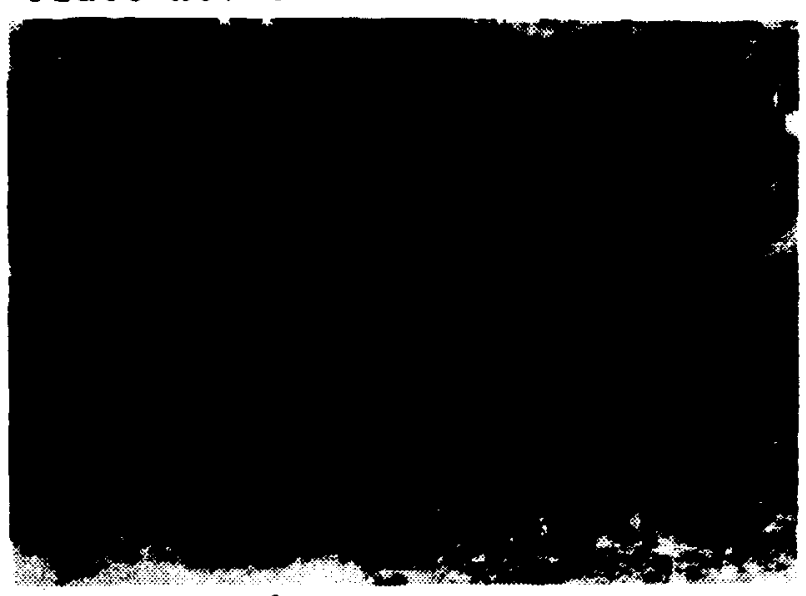

Plate no. 6

Fig. 7. X-ray radiographs of the examined plates 
THEle and autbor(s)

Raciographic Control of Mineral Fibre-Reinforced cerent plates

I. C. Domanus

Nuclear Departanent, Elsinore Shipbuilding \& Engineering Co.., Ltd. DK-3000 EeIsingor and I- Moller Jensen, Special Elber Department, Rockwool International Ite., DK-2640 Eedehusene

Hork performed under contract with Riso liational Laboratory.

\section{I: pages + 2 tables +7 inlustraecions}

Abstract

Paper accepted for presentation to the Third Interaztional Conference on Composite Materials is Paris, Erance, 26-29 August I980.

The usefulness of the radiographic technicue in the examination of Spinrock fibres reinforced cement glates was investigated with soft X-rays. A preliminary investigation hes shown that soft $\mathrm{X}$-rays are most suitable for radiography of cemert plates, and therefore a $50 \mathrm{kV} X-r a y$ machine with a $0.5 \mathrm{~mm}$ focus and beryliiun window $\mathrm{X}-$ ray tube was used throughout the investigation. $x$-ray filns of different speed and graininess were used. al:d it was proved that a zelatively fast kocak Industrex $D$ film can produce radiograpins of adequate quality. An Aça-Gevaert stzucturix IC zages can also be usec.

Radiographs of cemert plates, taken both on X-ray film and paper were scanned using a trensmission or reflection censitometer. Optical density seadings from the densitometer were fed into a paper chart recorder.

The results of the raciograpinic test were tzansfefed to a quantitative measure by densitometer scanrinf from which the relative stanjard deviations is thp optical densities were used. These measures show a significant correlation with the flexural strenfths, measured on the same specimens.

We therefore conclude that the material distribution can be measured by X-ray zadiography, and that this dist=ibution is a very important parameter for the eraluation of the qualify of cement plates reinforced with discontinuous mineral fibres.

Avallable on request fect Riso Librarf, Riso Nationai

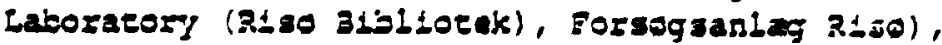
DK-4000 Roskilde, Denmar's Teleghona: (13) 37 :2 :2, axe. 2262. Talex: 43145 